Vol. 8(6), pp. 119-127, June, 2018

ISSN: 2276-7770; ICV: 6.15

Copyright $\odot 2018$, the copyright of this article is retained by the author(s)

DOI Link: http://doi.org/10.15580/GJAS.2018.6.053118075

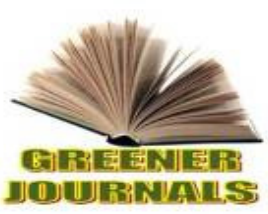

http://gjournals.org/GJAS

\title{
Effect of Partial Replacement of Dietary Soya Meal with Dried Azolla Pinnata Meal on the Performance and Egg Quality of Japanese Quails (Cortunix cortunix)
}

\author{
Alagbe J.O. ${ }^{1}$, Enam J.S. ${ }^{2}$ and Omokore E.A. ${ }^{3}$ \\ ${ }^{1}$ Poultry Department at Dan-malafia Farms Limited, Ibadan. \\ ${ }^{2}$ Department of Veterinary Pathology, Ahmadu Bello University, Zaria. \\ ${ }^{3}$ Federal Ministry of Agriculture and Rural Development, Abuja.
}

\section{ARTICLE INFO}

Article No.: 053118075

Type: Research

DOI: http://doi.org/10.15580/GJAS.2018.6.053118075

Submitted: $31 / 05 / 2018$

Accepted: 06/06/2018

Published: 22/06/2018

*Corresponding Author

Alagbe, J.O.

E-mail: demsonfarms@yahoo.com

Phone: +234 8066671794 ,

$+2348184729319$

Keywords: Japanese quails, Azolla meal, Soya meal, body weight and performance
An experiment was conducted to evaluate the effect of partial replacement of dietary Soya meal with dried Azolla pinnata meal in quail's diet. Five diets were formulated containing dried Azolla meal (AZL) at $0 \%$, $4 \%, 6 \%, 8 \%$ and $10 \%$ levels. One hundred and fifty laying quails at 16 weeks of age were used for this study. The quails were randomly allocated to five (5) dietary treatments replicated three times with each replicate having ten (10) quails in a completely randomized design (CRD). All necessary routine management practices were strictly observed. Feed and water were provided ad libitum. Data collected were subjected to one-way analysis of variance and means were separated using Duncan's multiple range test. Birds fed experimental diets showed no significant difference $(P>0.05)$ in final body weights, feed conversion ratio, daily water intake and feed cost per gram of egg. However, significant differences $(P<0.05)$ were observed for hen-day and henhoused production and other egg quality characteristics (egg weight, egg size, albumen weight, shell weight, shell thickness, yolk weight, yolk diameter, yolk width, yolk index and haugh unit). No mortality was recorded throughout the experiment which lasted for 60 days.

It can be concluded from this experiment that AZL could be incorporated up to $10 \%$ level in quails ration without any deleterious effect on the performance and health status of the birds. 


\section{INTRODUCTION}

Modern livestock production is faced with the challenges of producing high quality animal protein at low prices; there has also been an increase in the prices of conventional protein feedstuffs due to competition among ingredients used in the manufacture of animal feed. There is consequently a great need for alternatives that can supply in high demand for such ingredients, in particular for soya bean meal (Chisoro, 2015). Soybean meal is the most commonly used plant protein in livestock feeds but recently, it has become relatively expensive and scarce due to competitive demands in poultry and livestock feeding (Fagbenro et al., 2004). Soybean meal has long been considered an outstanding source of supplemental protein in diets for livestock and poultry. In fact, soybean meal is sometimes referred to as the "gold standard" because other protein sources are often compared to it. It is rich in highly digestible protein, and the protein is composed of a superior blend of amino acids, the building blocks of body protein for livestock and poultry.

The level of animal protein consumption in most developing countries of the world including Nigeria is very low. This low intake can be linked to high cost of the products arising mainly from high cost of production inputs, especially feed. Acute shortage and high cost of feedstuffs have been identified among other challenges as a major obstacle to the expansion of the poultry industry in the country (Abeke et al., 2003; Bawa et al., 2003). Economically viable livestock production systems depend on the use of inexpensive and easily available feed resource (Akinlade et al., 2004).

In view of the high cost of conventional feed ingredients, poultry nutritionists are looking for suitable alternatives to vegetable protein sources to reduce the production cost because as the human population increases, the poultry industry continues to grow to meet the demand for poultry products in world markets. According to Bacerra et al (1995) aquatic plant species, because of their growth habit, appear not to accumulate secondary plant compounds and therefore offer a greater potential than tree leaves as a source of protein for monogastric animals.

Azolla is an aquatic fern belonging to the family Azollaceae and order Pteridophyta. It grows naturally in stagnant water of drains, canals, ponds, rivers and marshy lands. According to Biplob et al (2002) six species are found in the tropics and subtropics. It is an unconventional feed ingredient for livestock (Pannerker, 1998). Azolla abhors symbiotic blue green alga (Anabaena azollae) which is responsible for the fixation of atmospheric oxygen inform of protein. Azolla is rich in essential amino acids, proteins, vitamins (vitamin $A$, vitamin B12 and B - carotene) and mineral like calcium, magnesium, potassium, phosphorus and copper. It binds nitrogen and produces nitrates and has been used to produce fertilizer in China for over 1000 years. The leaves from Azolla are little, sensitive and comes in different colour (Alalade and lyayi, 2006).

Azolla is one of the most nutritive aquatic plants, with high crude protein, carotenoid contents and good amino acid profile. It can be incorporated into the feed of fish (Nwanna and Falaye, 2009), pigs (Becerra et al., 1990), broiler chickens (Basak et al., 2002), ducks (Becerra et al., 1995), rabbits (Sreemannaryana et al., 1993), small ruminants (Tamang and Samanta, 1993) and ruminants (Nik-Khah and Motaghi-Talab, 1992).

Several research has been carried out on the effect of supplementing Azolla in the diet of broilers, for instance Biplop et al (2002) and Pinkihan , R. W (2013) reported a significant $(P<0.05)$ difference in final live weight and feed conversion ratio of broilers fed with $5 \%$ Azolla meal. Alalade et al. (2007) reported the nutritive value of azolla (Azolla pinnata) meal in the diets of growing pullets and subsequent effects on the laying performance. Khatun et al. (1996) studied the feeding value of azolla (Azolla pinnata) in laying hens in two feeding trials of 8 and 16 weeks duration. Sharma et al (2003) observed an increase in egg production when a fibre degrading enzyme was supplemented in a diet of 26 weeks old birds.

Therefore this study was carried out to investigate the effect of partial replacement of dietary Soya meal with dried Azolla pinnata meal in quail's diet.

\section{MATERIALS AND METHODS}

\section{Location of experiment}

The experiment was carried out at Dan-malafia Farms, Ibadan, Nigeria. The area is located within the derived savannah zone of Nigeria. The research was conducted between September to November, 2017.

Animals and their management

A total of One hundred and fifty (16 weeks old) laying quails were used for the study which lasted for 60 days. The quails were randomly allocated to five (5) dietary treatments replicated three times with each replicate having ten (10) quails in a completely randomized design (CRD). They were housed in cages whose floor was covered with wood shavings; feed and water were provided ad libitum.

\section{Parameters measured}

Quails were weighed at the beginning of the experiment and body weight changes was taken thereafter weekly, feed intake was calculated by difference between the feed offered and the left over, feed conversion ratio, feed cost $/ \mathrm{kg}$ and hen-day egg production, health of the experimental birds were carefully observed and mortality was recorded as it occurred. The eggs collected from each replicate group on 2nd, 4th 6th and 8th week were weighed and the average was taken as the egg weight per treatment. After weighing, three eggs from each 
replicate were randomly selected and used for egg quality analysis (Haugh unit, yolk height, yolk length and breadth, shell thickness). Yolk index was measured with a pair of Vernier calipers, shell thickness was also determined with a micrometer screw gauge. Haugh unit values were obtained from the formula below according to Haugh (1937):

$\mathrm{HU}=100 \log \left(\mathrm{H}+7.57 / 1.7 \mathrm{~W}^{0.37}\right)$

$\mathrm{HU}$ - Haugh unit (\%)

$\mathrm{H}$ - Height of albumen $(\mathrm{mm})$

W - Weight of the eggs $(\mathrm{g})$
Yolk weight was measured by separating the yolk from the albumen with the aid of a egg yolk separator and then weighed with an electronic sensitive scale. Cost per gram of eggs produced were calculated based on the current prices of the feed materials used. Health of the experimental birds and mortalities were carefully observed and recorded daily. Hen day and hen house production was also accessed.

Hen-day and hen housed production were calculated using the following formulae:

Hen-Day Egg Production (HDEP),

HDEP $=\frac{\text { Total number of eggs produced }}{\text { Total number of quails present }} \times 100$

Hen-Housed Egg Production (HHEP)

HHEP $=\frac{\text { Total number of eggs laid on a day }}{\text { Total number of quails housed at the beginning of laying period }} \times 100$

\section{Preparation of experimental diets}

Azolla (AZL) was collected from ponds within the farm premises and sundried for 6 days, it was later grinded and stored in a container. The test ingredient (AZL) was mixed with other ingredients to form five (5) experimental diets such that Azolla replaced Soya meal at levels of 0 , $10,20,30$ and $40 \%$. The proximate composition as presented in Table 1. The proximate composition of Azolla and Soya meal are presented on Table 2 and 3 respectively. Phytochemical chemical analysis of Azolla was conducted using standard methods as presented on Table 4.

The basal diet was formulated to meet the nutritional requirements of laying quails according to NRC (1994).

\section{Proximate Analysis}

The proximate analysis of the five experimental diets was determined according to AOAC (1990). Crude protein content of Azolla powder was determined by using Lowry et al (1951) method. Crude lipid was analyzed by Bragdon (1951).

\section{Statistical Analysis}

All data obtained were subjected to analysis of variance (ANOVA) according to Steel and Torrie (1980) and treatment means separated by Duncan multiple range test (Duncan, 1955). 
Table 1: Percentage Composition of the Experimental Diets

\begin{tabular}{|c|c|c|c|c|c|}
\hline Ingredients & & Die & & & \\
\hline & 1 & 2 & 3 & 4 & 5 \\
\hline Maize & 46.0 & 46.0 & 46.0 & 46.0 & 46.0 \\
\hline Wheat offal & 21.25 & 21.25 & 21.25 & 21.25 & 21.25 \\
\hline Soya Meal & 20.0 & 16.0 & 14.0 & 12.0 & 10.0 \\
\hline Azolla Meal (AZL) & 0.0 & 4.00 & 6.00 & 8.00 & 10.0 \\
\hline Groundnut Cake & 10.0 & 10.0 & 10.0 & 10.0 & 10.0 \\
\hline Bone meal & 1.5 & 1.5 & 1.5 & 1.5 & 1.5 \\
\hline Oyster shell & 0.5 & 0.5 & 0.5 & 0.5 & 0.5 \\
\hline G/Premix & 0.25 & 0.25 & 0.25 & 0.25 & 0.25 \\
\hline Salt & 0.50 & 0.50 & 0.50 & 0.50 & 0.50 \\
\hline & 100 & 100 & 100 & 100 & 100 \\
\hline Determined Analysis & & & & & \\
\hline Crude Protein (\%) & 20.06 & 20.05 & 20.04 & 20.03 & 20.01 \\
\hline Crude Fibre (\%) & 4.10 & 4.10 & 4.10 & 4.10 & 4.10 \\
\hline Ether extract (\%) & 3.74 & 3.74 & 3.74 & 3.74 & 3.74 \\
\hline Ash (\%) & 3.6 & 3.6 & 3.6 & 3.6 & 3.6 \\
\hline Metabolizable energy (Kcal/kg) & 2702.0 & 2706.0 & 2705.0 & 2705.1 & 2706.1 \\
\hline Calcium (\%) & 3.20 & 3.20 & 3.20 & 3.20 & 3.20 \\
\hline Methionine (\%) & 0.45 & 0.45 & 0.45 & 0.45 & 0.45 \\
\hline Cost /Kg (N) & 83.76 & 81.04 & 81.03 & 81.02 & 81.01 \\
\hline $\begin{array}{l}\text { "Vitamin -mineral premix contai } \\
\text { 20mg; Choline chloride, } 400 \mathrm{mg} \\
\text { Zinc, } 45 \mathrm{mg} \text {; Cobalt, } 0.02 \mathrm{mg} .\end{array}$ & $\begin{array}{l}\text { A } 8,000 \\
\text { janese, } 1\end{array}$ & it D3, 200 & $\begin{array}{l}\text { U; Vit E, } 1 \\
\text {; Copper, }\end{array}$ & $\begin{array}{l}\mathrm{B} 2,10 \\
\text { lodine, }\end{array}$ & $\begin{array}{l}\text { B3, 30n } \\
\text { Seleniu }\end{array}$ \\
\hline & : Proxim & Jomposit & of Azolla & & \\
\hline Nutrients & & & $\% \mathrm{DM}$ & & \\
\hline Crude Protein & & & 21.93 & & \\
\hline Crude Fibre & & & 13.34 & & \\
\hline Ether extracts & & & 3.01 & & \\
\hline Ash & & & 17.51 & & \\
\hline Nitrogen Free Extract & & & 34.21 & & \\
\hline Minerals (Mg/kg) & & & & & \\
\hline Calcium & & & 2.11 & & \\
\hline Phosphorus & & & 0.70 & & \\
\hline Magnesium & & & 0.11 & & \\
\hline
\end{tabular}

Table 3: Proximate composition of Soya bean meal

\begin{tabular}{lc}
\hline Parameter & Dry matter (\%) \\
\hline Crude protein & 43.00 \\
Crude fibre & 6.53 \\
Total Ash & 8.95 \\
Ether extracts & 6.21 \\
NFE & 25.60 \\
Dry matter & 90.29 \\
Minerals (mg/kg) & \\
Sodium & 15.12 \\
Calcium & 38.51 \\
Magnesium & 3.76 \\
\hline NFE Nitrogen free
\end{tabular}

NFE - Nitrogen free extracts 
Table 4: Phytochemistry of AZL

\begin{tabular}{lc}
\hline Parameters & Quantity \\
\hline Saponin (\%) & 0.75 \\
Tannin (\%) & 0.89 \\
Phenols (\%) & 1.30 \\
Steroids (\%) & 1.60 \\
Alkaloids (\%) & 2.06 \\
Flavonoids (\%) & 4.11 \\
Phytate (mg/g) & 10.22 \\
\hline
\end{tabular}

Table 5: Growth Performance of Japanese quails fed AZL as partial replacement for SBM

\begin{tabular}{|c|c|c|c|c|c|c|c|}
\hline \multicolumn{8}{|c|}{ Diets } \\
\hline Parameters & 1 & 2 & 3 & 4 & 5 & SEM & $S / L$ \\
\hline Number of quails & 30 & 30 & 30 & 30 & 30 & - & \\
\hline Initial body weight $(\mathrm{g})$ & 199.3 & 199.0 & 198.0 & 198.2 & 198.1 & 1.07 & N.S \\
\hline Final body weight (g) & 290.6 & 296.4 & 290.9 & 290.1 & 295.2 & 1.23 & N.S \\
\hline Daily feed intake $(\mathrm{g})$ & 27.60 & 27.88 & 27.06 & 27.10 & 27.01 & 1.10 & N.S \\
\hline Daily weight gain $(\mathrm{g})$ & 0.26 & 0.27 & 0.28 & 0.26 & 0.31 & 0.07 & N.S \\
\hline Hen day Production (\%) & $77.1^{\mathrm{c}}$ & $77.06^{a}$ & $77.04^{\mathrm{b}}$ & $77.05^{\mathrm{a}}$ & $77.03^{b}$ & 2.06 & S.D \\
\hline Hen House Production (\%) & $75.10^{\mathrm{a}}$ & $74.90^{\mathrm{b}}$ & $75.06^{c}$ & $75.11^{\mathrm{b}}$ & $75.10^{c}$ & 2.60 & S.D \\
\hline Feed conversion ratio & 3.31 & 3.54 & 3.62 & 3.68 & 3.71 & 0.05 & N.S \\
\hline Daily water intake (ml/day) & 702 & 709 & 715 & 702 & 705 & 3.10 & N.S \\
\hline Feed cost per gram of egg $(\mathrm{N})$ & 0.41 & 0.42 & 0.42 & 0.43 & 0.43 & 0.02 & N.S \\
\hline Mortality & 0.00 & 0.00 & 0.00 & 0.00 & 0.00 & - & \\
\hline
\end{tabular}

${ }_{\mathrm{abc}}$ means different superscript along rows differs significantly at $\mathrm{P}<0.05$

N.S - No significant difference

S.D - Significant difference

Table 6: Egg quality characteristics of Japanese quails fed AZL as a partial replacement for SBM

\begin{tabular}{|c|c|c|c|c|c|c|c|}
\hline \multirow[b]{2}{*}{ Parameters } & \multicolumn{5}{|c|}{ Diets } & \multirow[b]{2}{*}{ SEM } & \multirow[b]{2}{*}{$S / L$} \\
\hline & 1 & 2 & 3 & 4 & 5 & & \\
\hline$\overline{\text { Egg weight (g) }}$ & $9.90^{c}$ & $13.1^{\mathrm{c}}$ & $13.3^{b}$ & $13.0^{b}$ & $13.4^{\mathrm{a}}$ & 0.28 & $\overline{S . D}$ \\
\hline Egg size $(\mathrm{cm})$ & 2.09 & 3.09 & 3.20 & 3.07 & 3.06 & 0.14 & S.D \\
\hline Albumen weight (g) & 6.11 & 6.08 & 6.07 & 6.08 & 6.06 & 0.12 & S.D \\
\hline Shell weight (g) & $0.47^{c}$ & $0.89^{\mathrm{a}}$ & $0.81^{c}$ & $0.86^{a}$ & $0.82^{b}$ & 0.02 & S.D \\
\hline Shell thickness $(\mathrm{cm})$ & $0.36^{c}$ & $0.61^{b}$ & $0.64^{\mathrm{b}}$ & $0.69^{a}$ & $0.79^{a}$ & 0.31 & S.D \\
\hline Yolk index & 0.19 & 0.28 & 0.29 & 0.29 & 0.30 & 0.18 & S.D \\
\hline Yolk weight (g) & 1.65 & 2.76 & 2.45 & 2.63 & 2.70 & 0.01 & S.D \\
\hline Yolk diameter (cm) & 1.60 & 2.41 & 2.46 & 2.66 & 2.73 & 0.02 & S.D \\
\hline Yolk width (cm) & 1.81 & 2.39 & 2.61 & 2.56 & 2.45 & 0.01 & S.D \\
\hline Haugh unit (\%) & 80.70 & 91.03 & 94.60 & 95.11 & 96.06 & 0.07 & S.D \\
\hline
\end{tabular}

abc means different superscript along rows differs significantly at $\mathrm{P}<0.05$

N.S - No significant difference

S.D - Significant difference 
Figure 1. Growth performance of Japanese quails fed AZL as partial replacement for SBM
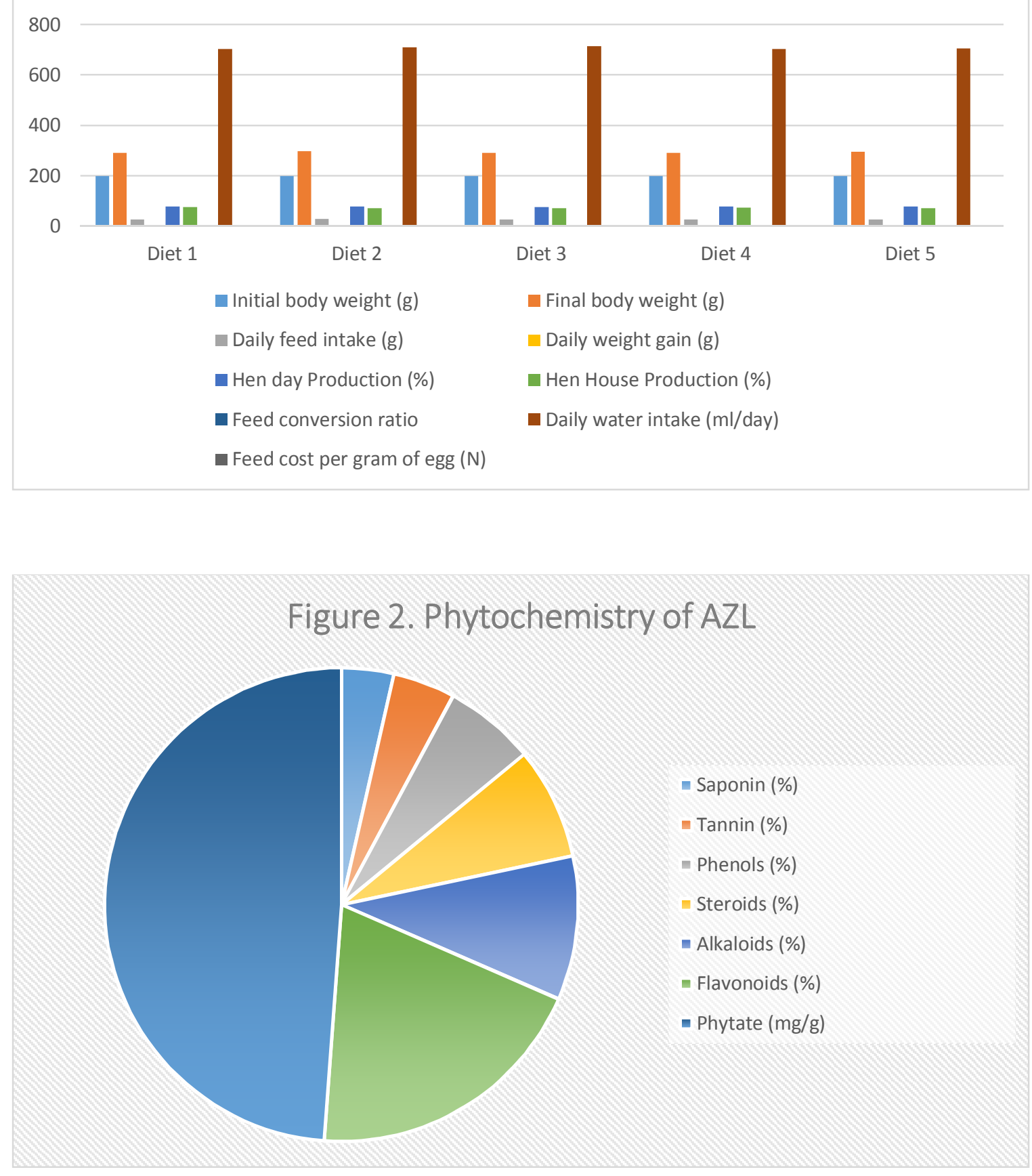

\section{RESULTS}

Table 1 reveals the percentage composition of the experimental diet. The crude protein ranges between $20.01-20.06 \%$. The metabolizable energy values obtained are 2702.0, 2704.0, 2705.0, 2705.1 and 2706.1 (Kcal/kg) for diets 1, 2, 3, 4 and 5 respectively while those of cost per kg of feed are $\$ 83.76, \$ 81.04, \$ 81.03$, \# 81.02 and 81.01 for diets $1,2,3,4$ and 5 respectively.
Table 2, shows the proximate composition of Azolla pinnata powder. The proximate components are $21.93 \%, 13.34 \%, 3.01 \%, 17.51 \%, 34.21 \%, 2.11,0.70$ and $0.11(\mathrm{mg} / \mathrm{kg})$ for crude protein, crude fibre, ether extract, ash, nitrogen free extract, calcium, phosphorus and magnesium for diets 1, 2, 3, 4 and 5 respectively.

The proximate composition of soya bean meal is presented in Table 3 . The proximate component values are $43.00 \%, 6.53 \%, 8.95 \%, 6.21 \%, 25.60 \%, 15.12$, $38.51,3.76(\mathrm{mg} / \mathrm{kg})$ for crude protein, crude fibre, ash, ether extract, nitrogen free extract, calcium, phosphorus 
and magnesium for diets $1,2,3,4$ and 5 respectively. Phytochemical analysis of Azolla shows that it contained saponin, tannin, phenol, steroids, alkaloids, flavonoids and phytate at $0.75 \%, 0.89 \%, 1.30 \%, 1.60 \%, 2.06 \%$, $4.11 \%$ and $10.22 \mathrm{mg} / \mathrm{g}$ as presented in Table 4.

The growth performance values of quails fed AZL as a partial replacement for SBM are presented in Table 5, the final body weight ranges between 290.6 and 296.4g. The daily feed intake values obtained are 27.60 , 27.88, 27.06, 27.10 and $27.01 \mathrm{~g}$ for diets $1,2,3,4$ and 5 respectively while those of daily weight gain are 0.26 , $0.27,0.28,0.26$ and $0.31 \mathrm{~g}$ for diets $1,2,3,4$ and 5 respectively. The final weight, daily feed intake and daily weight gain were not significantly affected $(P>0.05)$ by partial replacement for SBM with AZL. The feed intake values obtained are $27.60 \mathrm{~g}, 27.88 \mathrm{~g}, 27.06 \mathrm{~g}, 27.10 \mathrm{~g}$ and $27.01 \mathrm{~g}$ for diets $1,2,3,4$ and 5 respectively. Hen day production values obtained are $77.1,77.06,77.04,77.05$ and $77.03(\%)$ for diets $1,2,3,4$ and 5 respectively while those of hen house production (\%) are 75.10, 74.90, $75.06,75.11$ and 75.10 respectively. The daily feed intake, daily weight gain, feed conversion ratio, daily water intake and feed cost per gram of egg were not significantly $(P>0.05)$ different among the dietary treatments although the daily water intake and feed cost per gram of egg increased from diet 1 to 3 and the values later declined. No mortalities were recorded among the treatment groups throughout the experimental period.

Table 6 shows the egg quality of Japanese quails fed AZL as a partial replacement for SBM. The egg weight values obtained are 9.90, 13.1, 13.3, 13.0 and $13.4(\mathrm{~g})$ for diets $1,2,3,4$ and 5 respectively while those of egg size $(\mathrm{cm})$ are 2.09, 3.09, 3.20, 3.07 and 3.06 respectively. The albumen weight values obtained are $6.11,6.08,6.07,6.08$ and $6.06 \mathrm{~g}$ ) for diets $1,2,3,4$ and 5 respectively. The egg weight, egg size, albumen weight, yolk index, yolk weight, diameter and width values were significantly affected $(P<0.05)$ by the partial replacement of SBM with AZL. Shell weight values are $0.47 \mathrm{~g}, 0.89 \mathrm{~g}, 0.81 \mathrm{~g}, 0.86 \mathrm{~g}$ and $0.82 \mathrm{~g}$ for diets $1,2,3,4$ and 5 respectively while those of shell thickness values are $0.36,0.61,0.64,0.69$ and $0.79(\mathrm{~cm})$ for diets $1,2,3$, 4 and 5 respectively. Shell weight and thickness were significantly $(\mathrm{P}<0.05)$ different among the dietary treatments. The Haugh unit values obtained are 80.70 , 91.03, 94.60, 95.11 and $96.06(\%)$ for diets 1, 2, 3, 4 and 5 respectively.

\section{DISCUSSION}

The crude protein in the experimental diet slightly increased from diet 1 to 5 , which is consistent with the finding of Pannaerker (1988). According to NRC (1994) quails in the production periods require protein level of $20 \%$. The proximate composition of Azolla powder was similar with the finding of Raseena (2006) and Alalade and lyayi (2006) on the chemical composition and feeding value of Azolla (Azolla pinnata) meal for egg type chicks but contrary to the reports of Biplob (2002); Singh (1977); Sreemannaryana et al. (1993) on the protein fractionation and in vitro digestibility of Azolla in ruminants. The differences in the proximate values could be attributed to differences in strains of Azolla. According to Ali et al (1995) and Termany et al (1992) environmental factors could affect the morphology and chemical of Azolla.

The result of phytochemical analysis of AZL in this current study was also consistent with report of Abraham and Vidhu (2012); Mithiraja et al (2011) and Arai (1998) on the phytochemical constituents of Azolla.

Partial replacement of SBM with AZL in the diets of laying quails showed no significant $(P>0.05)$ effect on their final live weight, feed intake, daily weight gain and feed conversion ratio (FCR) in the current study. This was similar with the finding of Gakuya et al. (2014) and Bhuyan et al (1998) on the effect of Azolla on the performance of broilers but contrary to the report of Canogullari et al (2010) on the effects of dietary garlic powder on the performance, egg yolk and serum cholesterol concentrations in laying quails. The increase in the feed consumption of quails in diet 2 could be as a result of increased palatability. HDEP and HHEP were significantly $(P<0.05)$ different among the treatments, their values was slightly higher for birds fed diets containing $0 \%$ AZL at a significant level. This current study was contrary with Reijrink et al (2010b ) who reported that egg production were not affected when garlic oil was supplemented in the diets of quails. In contrast, Oluwabamiwa et al (1999) reported a lower value $(60-67 \%)$ in hen day production when different cocoa based rations were experimented on the productive performance of Japanese quails. Dietary treatments had no significant $(P>0.05)$ effect on daily water intake and feed cost per gram of egg. The water intake slightly increased from diet 1 to 3 after which the values declined. The current study was in line with Odunsi et al., (2011) who reported similar results on feed cost per gram of feed when maize, sorghum, millet and biscuit waste meal was used as energy sources in the diet of Japanese quails. Economically diet 1 and 5 are best when producing a gram of egg, the least cost per kilogram in diet 1 and 4 translated to better egg production, this is consistent with the findings of Fanimo et al (2007) when accessing the feeding value of cashew nut in the testa of broilers.

The significant $(P<0.05)$ differences in the values obtained for egg weight, egg size and albumen weight is contrary with the report of Odunsi et al (2007) but in agreement to the reports of Kaijage et al. (2004) on the effects of Moringa leaf meal on egg quality characteristics. Quails fed diet 1 had a higher egg weight followed by diet 5, 4, 3 and 2 respectively. This suggests a good quality in the feed given to the birds. According to Fakhraei et al. (2010) good quality feed contains balanced essential amino acid which are responsible for better egg weight and overall production. These might explain the reasons why quails fed diet 2, 3, 4 and 5 had a better feed conversion ratio and egg production, this 
observation is consistent with the findings of Niekerk (2014) who reported that there is a direct link between dietary proteins supplied and egg production translating to good FCR.

Nobakht and Mehmannavaz (2010) showed that increasing yolk weight was the main reason for the increment in albumen weight and this might explain the increase in albumen weight in groups fed diets supplemented with AZL. Nobakht and Moghaddam (2012) also noted a positive correlation between Haugh unit and quality of egg components (yolk and albumin). Egg albumen height and egg weight are indices for evaluation of Haugh unit. The Increase in the egg weight might be due to an increase in the weight of albumen and yolk especially for diet 5 which is also reflected in the Haugh unit in this present study. AZL is a good pigmenting agent of poultry products due to its rich Bcarotene ((Alalade and lyayi, 2006). content .The yolk

\section{REFERENCES}

Abeke, F.O., Ogundipe, S.O., Sekoni, A.A., Dafwang, I.I. and Oladele, S.B. (2003). Effect of Duration of Cooking Lablab Beans on Organ Weight and Blood Parameters of Pullet Chicks. Proceedings of the $28^{\text {th }}$ Annual Conference of the Nigerian Society for Animal Production, Ibadan. 28: 240-242.

Abraham, G and Vidhu, Aeri (2012). Preliminary profile of Azolla microphylla with respect to seasons. apjtb S1392- S1395.

Akinlade, A. A., Akingbade, J. A and Aderinola, O. A (2004) Basic concepts in pasture science. Positive press Pages 38-39.

Alalade OA and lyayi EA (2006). Chemical composition and feeding value of Azolla (Azolla pinnata) meal for egg type chicks. International Journal of Poultry Science, 5: 137-141.

Ali, M.A. and S. Leeson, 1995. The nutritive value of some indigenous Asian poultry feed ingredients. Anim. Feed Sci. and Tech., 55:227-237.

Ali MA and Leeson S (1995). Azolla" Biology and agronomic significance. Botanical Review, 35: 1735.

AOAC, 1990. Official method of Analysis, 13 edn. Association of official analytical chemists, Washington DC.

Arai, Y., Nakagwa, T., Hitosugi, M., Shiojima, K., Ageta, $H$ and Abdelhalim, O.B (1998). Chemical constituents of aquatic fern Azolla nilotica phytochemistry, 48: 471-474.

Bacerra M, Preston TR and Ogle B (1995). Effect of replacing whole boiled soya beans with azolla in the

Fagbenro, O.A., Akande, T.T., Fapohunda, O.O. and Akegbejo-Samsons, Y. (2004). Comparative assessment of roselle (Hibiscus sabdariffa variety. Sabdariffa) seed meal and kenaf (Hibiscus sabdariffa variety. Altissima) seed meal as replacement for soyabean meal in practical diets for fingerlings of nile tilapia, Oreochromis Niloticus color showed an increasing trend as the amount of AZL increased in the ration.

The inclusion of aquatic plants at low levels in poultry diets had shown better performance especially when they supply part of the total protein, they serve as a source of pigment for egg yolk (Maurice et al., 1984). According to Becerra et al., 1995 AZL contains high xanthophyll content which makes them superior to alfalfa meal in imparting colour to egg yolk and poultry skin pigmentation.

\section{CONCLUSIONS}

From this study, it was concluded that AZL could be included in quails diet up to $10.0 \%$ level without loss in overall performance of laying birds.

diets of growing ducks. Livestock Research for Rural Development, 7: 1-11.

Bawa, G.S., Tegbe, T.S.B. and Ogundipe, S.O. (2003). Effect of Feeding Graded Levels of Lablab Seeds as a replacement for Soya beans on Performance Characteristics of Young Pigs. Proceedings of the $28^{\text {th }}$ Nigerian Society for Animal Production conference, Ibadan, 28: 230-232.

Bhuyan, M. A. H., M. R. Hasanat, M. A. Ali and M. A. Rahman, 1998. Effect of feeding Azolla (Azolla pinnata) on the performance of broiler. Bangladesh J. Anim. Sci., 27(1 \& 2):77-82.

Biplob Basak, Md. Ahsan Habib Pramanik, Muhammad Siddiqur Rahman, Sharif Uddin Tarafdar and Bimol Chandra Roy (2002). Azolla (Azolla pinnata) as a Feed Ingredient in Broiler Ration. International Journal of Poultry Science 1 (1): 29-34, 2002.

Biplob Basak, Md. Ahsan Habib Pramanik, Muhammad Siddiqur Rahman, Sharif Uddin Tarafdar and Bimol Chandra Roy (2002). Azolla (Azolla pinnata) as a Feed Ingredient in Broiler Ration. International Journal of Poultry Science 1 (1): 29-34, 2002.

Bragdon, J. H (1951). Colorimetric determination of blood lipids J. Bio. Chem. 190-193.

Canogullari, S., Baylan. M., Erdogan, V., Duzguner, A and Kucukgul, A (2010). The effect of dietary garlic powder on the performance, egg yolk and serum cholesterol concentrations in laying quails. Czech Journal of Animal Science. 55, 2010(7):286-293.

Chinsoro, Prince (2015). Potential use of baobab seeds in poultry diets, department of livestock and pasture science. Faculty of Science and Agriculture, University of Fort Hare. Pp 52-53

Fakhraei, J., Loutfollahian, H., Shivazad, M., Chamani, M. and Hoseini S. (2010): Reevaluation of lysine requirement based on performance responses in broiler breeder hens. Afric. J. of Agri. Rese., 5(16): 2137-2142.

Fanimo, A.O., Adebayo, A.S., Oduguwa, $0 . O$ and Biobaku, W.O (2007). Feeding value of cashew nut 
testa for broiler chickens. Nig. J. Anim. Prod. 34-8393.

Gakuya, D., Mbugua, P., Mwaniki, S., Kiama S., Muchemi, G. and Njuguna, A. (2014): Effect of Supplementation of Moringa oleifera (LAM) Leaf Meal in Layer Chicken Feed. Int. J. Poult. Sci., 13 (7): 379-384.

Gakuya, D., Mbugua, P., Mwaniki, S., Kiama S., Muchemi, G. and Njuguna, A. (2014): Effect of Supplementation of Moringa oleifera (LAM) Leaf Meal in Layer Chicken Feed. Int. J. Poult. Sci., 13 (7): 379-384.

Haugh, R. R. (1937). The Haugh unit for measuring egg quality.US Poult. Mag. 43:552-573.

Kaijage, J., Sarwatt, S. and Mutayoba, S. (2004): Moringa oleifera leaf meal can improve quality characteristics and consumer preference of marketable eggs. Pp 126-129.

Khatun, M. A., (1996). Utilization of Azolla (Azolla pinnata) in the diet of laying hen. M. S. thesis, Deptt. Of Poultry Science, B A. U. Mymensingh.

Lowry, O.H., Rosebrough, N. J., Farr, A. L and Randall, R. J (1951). J. Biol. Chem; 193-265.

Mithraja. M. J., Antonisamy, J.M., Mahesh, M., Paul, M. $Z$ and Jeeva, S (2011). Phytochemical studies on Azolla pinnata. Apjtb S 26-S 29.

Niekerk, V. (2014): Egg quality. Low Input Breeds technical note. Pp 24.

Nik-Khah, A. \& M. Motaghi-Talab. (1992). The use of Azolla in lactating cows. Iranian J. Agric. Sci. 23: 4756.

Nobakht, A. and Mehmannavaz, Y. (2010): Investigation the effects of using different levels of Thymyus valgaris, Lamiaceae men-thapiperita and Oreganum valgare and their different mixtures on yield, egg quality, blood and immunity parameters of laying hens. Iranian J. Anim. Sci., 41:129-136

Nobakht, A. and Moghaddam, M. (2012): The Effects of Different Levels of Costmary (Tanacetum balsamita) Medicinal Plant on Performance, Egg Traits and Blood Biochemical Parameters of Laying Hens. Iranian J. Anim. Sci., 27:125-130.

NRC, 1994. Composition of feed stuff used in Poultry diets in Nutrient requirements of Poultry. National Academy Press Washington, DC. pp: 61-75.

Nwanna, L.C., A.E. Falaye,O.J. Olarewaju and B.V. Oludapo (2009), Evaluation of Nile Tilapia (Oreochromis niloticus L) Fed Dietary potato peels as replacement for yellow maize. Proceedings of the $24^{\text {th }}$ Annual Conference of the Fisheries Society of Nigeria, Federal University of Technology, Akure. 25-28 October, 2009: 155-158.
Odunsi, A., Sanusi, T.O and Ogunleye, J.B (2007): Comparative evaluation of maize, sorghum, millet, biscuit waste meal as energy sources for Japanese quails in a derived savannah zone of Nigeria. International Journal of Applied Agricultural and Apicultural Research. IJAAAR 4(1\&2): 90-96, 2007.

Odunsi, A., Ogunleke, M., Alagbe, O. and Ajani, T. (2011): Effect of feeding Gliricidia sepium leaf meal on the performance and egg quality of layers. Int. J. Poult. Sci., 1:26-29.

Olubamiwa, O., Harunna, E. S., Musa, V., Akinwale, T.O., Lambin, L.H and Longe, O.G (1999). Effect of different level of energy levels of cocoa based rations on productive performance of quails. Nig. J. Anim. Prod. 26:88-92.

Pannaerker S (1988). Azolla as a livestock and poultry feed. Livestock Adviser, 13: 22-26.

Raseena (2006). Effect of dietary supplementation of Azolla (A. pinnata) on production performance in Japanese quail (Coturnix coturnix japonica). M.V.Sc. thesis submitted to Kerala Agricultural University, Thrissur, India.

Reijrink, I., Meijerhof, B., Kemp, L. and van den Brand, $\mathrm{H}$. (2010b): Influence of egg warming during storage and hypercapnic incubation on egg characteristics, embryo development, hatchability, and chick quality. Poult. Sci., 89: 2470-2483

Sharma, K. S., P. Gupta, K. Meena and R. Desv, 2003. Effect of intermittent dietary supplementation of different combinations of microbial strains, on the biological performance of commercial layer chicken. Proceeding of the 21th Conference of Indian Poultry Science Association and National Symposium on Diversification of Poultry for Nutritional Security, March 27-28, 2003, Izatnagar, India, pp: 112-112.

Singh, P. K., 1977. Azolla plants as fertilizer and feed Indian Farming, 27:19

Sreemannaryana, D., K. Ramachandraiah, K. M. Sudarshan, N. V. Romanaiah and J. Ramaprasad (1993) Utilization of Azolla as a rabbit feed. Indian vet. J., 70: 285-286.

Steel, R. G. D. and J. H. Torrie, 1980. In: Principal and Procedure of Statistics: A Biometrical Approach. McGraw Hill, New York.

Tamang, Y. and G. Samanta, (1993) Feeding value of azolla (Azolla pinnata) an aquatic fern in Black Bengal goats. Indian J. Anim. Sci., 63:188-191.

Tamany, Y., G. Samanta, N. Chakraborty and L. Mondal, 1992. Nutritive value of Azolla (Azolla pinnata) and its potentiality of feeding in goats. Environment and Ecology, 10:755-756. 